\title{
微細結晶粒を持つ $\mathrm{Mg}-\mathrm{Al}-\mathrm{Zn}$ 系 $\mathrm{Mg}$ 合金の 摩擦攪拌接合継手強度に及ぼすツール形状の影響
}

\author{
山本尚 嗣 1 廖 金 孫 1 中田一 博 $^{2}$
}

1株式会社栗本鐵工所技術開発本部

2 大阪大学接合科学研究所

J. Japan Inst. Metals, Vol. 75, No. 2 (2011), pp. 91-96

(C) 2011 The Japan Institute of Metals

\section{Effect of Tool Shape on Friction Stir Welded Joint Strength of Fine-Grained Mg-Al-Zn Magnesium Alloy}

Naotsugu Yamamoto ${ }^{1}$, Jinsun Liao ${ }^{1}$ and Kazuhiro Nakata ${ }^{2}$

${ }^{1}$ Technology Development Headquarters, Kurimoto Ltd., Osaka 559-0021

${ }_{2}^{2}$ Joining and Welding Research Institute, Osaka University, Osaka 567-0047

Friction stir welding was applied to join a fine-grained high tensile strength AZ31 alloy and a commercially extruded AZ31 alloy, and the effect of tool shape on the joint strength of the two magnesium alloys was investigated. For the commercially extruded AZ31 alloy with mean grain size of ca. $11 \mu \mathrm{m}$, the tool shape has almost no influence on the joint strength; for the finegrained AZ31 alloy with mean grain size of ca. $1.9 \mu \mathrm{m}$, however, the joint strength was strongly influenced by the tool shape. The joint strength of the fine-grained AZ31 alloy increases with the ratio of shoulder diameter to probe diameter. It is found that the texture in the stir zone changes with the tool shape, which is one of the predominant factors controlling the joint strength of the fine-grained AZ31 alloy.

(Received September 16, 2010; Accepted October 14, 2010)

Keywords: $M g-A l-Z n$ magnesium alloy, friction stir welding, mechanical properties, texture, fine grain, electron backscatter diffraction $(E B S D)$

\section{1. 緒言}

1991 年に英国の溶接研究所において開発された摩擦攪汼 接合 (Friction Stir Welding : 以下 FSW) は, 近年新しい接 合法として注目を集め, 航空宇宙産業, 自動車, 船舶, 車両 など多くの分野に抢いてその実用化に向けての基礎研究およ び応用研究が活発に行われて抢り，アルミニウム合金(以下 $\mathrm{Al}$ 合金)に沶いてはすでに実用化されている，マグネシウム 合金(以下 $\mathrm{Mg}$ 合金)に関しても研究がなされており，AZ31 合金 ${ }^{1,2)}, A Z 61$ 合金 ${ }^{3,4)}, A Z 91$ 合金5,6), 難燃性 $M g$ 合金 ${ }^{7)}$, 耐熱 $\mathrm{Mg}$ 合金継手8) および微細結晶粒を有する高強度 $\mathrm{Mg}$ 合 金9,10)に関するものがあり, 継手強度は母材引張強度の約 80 〜 $100 \%$ と報告されている. また，これらの報告の中で， $\mathrm{Mg}$ 合金の FSW 継手強度の低下要因の一つとして攪挥部に 形成される集合組織が挙げられている. 特に, 母材組織の結 晶粒径が小さく攪拌部に形成される動的再結晶組織が母材と 同程度もしくは大きくなる場合, 継手強度に対する集合組織 の影響は顕著になると考えられる(押出材や鋳物など母材の) 結晶粒が数十 $\mu \mathrm{m}$ 以上の場合, 攪拌部の組織は動的再結晶に より微細化されるため接合部の強度が向上していると考えら れる). しかしながら, 微細結晶粒を持つ $\mathrm{Mg}$ 合金の FSW
継手の接合部に形成される集合組織と継手強度との関係を系 統的に調査した報告は見受けられない。そこで, 本研究で は, 強加工法の一つである RCP ( Roll Compaction Process) ${ }^{11,12)}$ により結晶粒が微細化された高強度 $\mathrm{Mg}-\mathrm{Al}-\mathrm{Zn}$ 系 AZ31 合金 (以下 RCPAZ31) 抢よび AZ31 押出材 (以下 AZ31) に様々な形状のツールを用いて FSWを適用し, 得ら れた継手の組織と機械的性質の関係を調査した.

\section{2. 実 験 方 法}

供試材は RCP AZ31 合金および AZ31 である. 試験片の 形状は幅 $75 \mathrm{~mm} \times$ 長さ $250 \mathrm{~mm} \times$ 厚さ $2 \mathrm{~mm}$ である. その 化学組成を Table 1 に示す. 接合方向は, 供試材の押出方向 に平行とし, I 型突合せ接合を行った。 また, 接合面は, 接 合直前にエメリー紙 (\#800)で磨いた後, アセトン脱脂を行 った.

回転ツールの形状および接合条件を Table 2 に示す. 回転 ツールは焼入工具鋼 $(\mathrm{SKD} 61)$ 製でネジ有のものを使用し た. 接合は, プローブを素材の接合開始位置に挿入し，ショ ルダが素材に接してから 2 秒間の予熱後 Table 2 に示す接合 条件により行った。

接合部外観検査ならびにマクロおよびミクロ組織観察によ 
Table 1 Chemical compositions of specimens used.

\begin{tabular}{|c|c|c|c|c|c|c|c|c|}
\hline \multirow{2}{*}{ Alloy } & \multicolumn{8}{|c|}{ Chemical compositions (mass\%) } \\
\hline & $\mathrm{Si}$ & $\mathrm{Mn}$ & $\mathrm{Cu}$ & $\mathrm{Zn}$ & $\mathrm{Al}$ & $\mathrm{Fe}$ & $\mathrm{Ni}$ & $\mathrm{Mg}$ \\
\hline AZ31 & $\leqq 0.10$ & $0.2 \sim 1.0$ & $\leqq 0.05$ & $0.6 \sim 1.4$ & $2.5 \sim 3.5$ & $\leqq 0.005$ & $\leqq 0.005$ & Bal. \\
\hline
\end{tabular}

Table 2 Tool dimensions and FSW conditions.

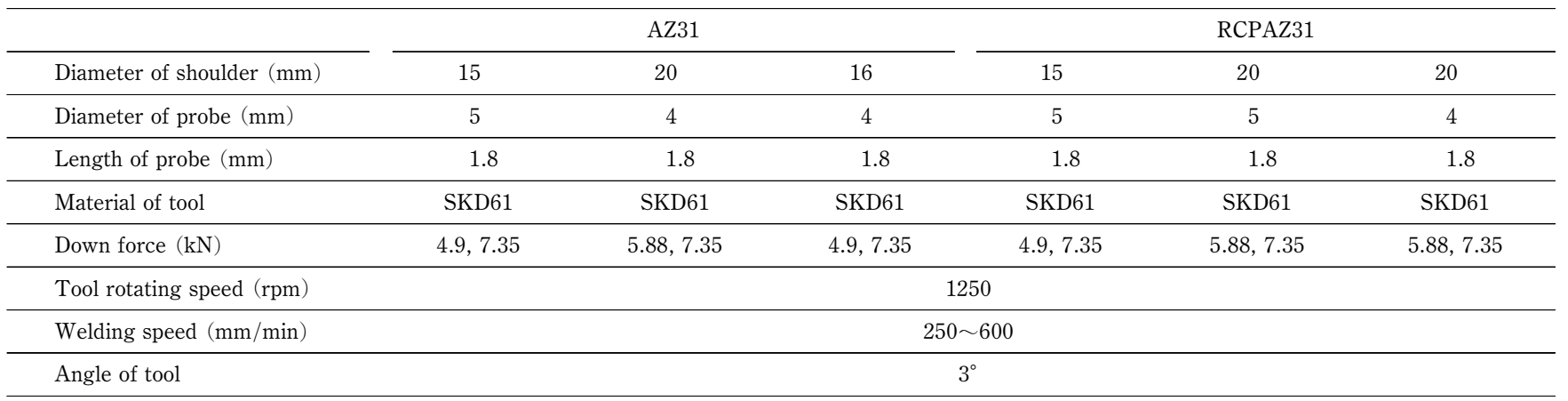

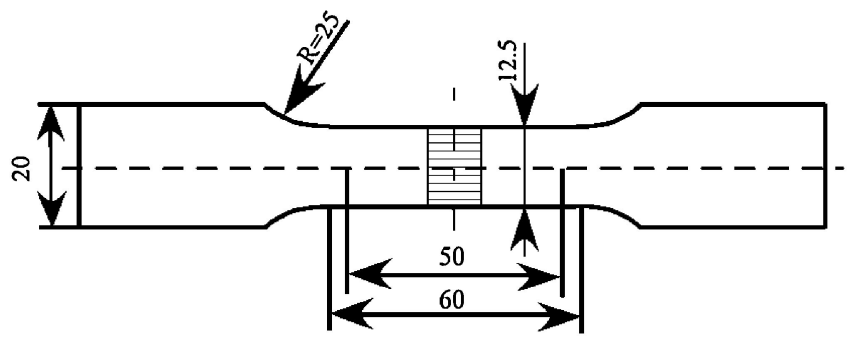

Fig. 1 Dimensions of test pieces for the tensile test.

り接合部のキッシングボンドおよび割れ等の欠皕発生の評価 を行った。マクロおよびミクロ組織観察は, 研磨後, 腐食液 ピクリン酸(ピクリン酸 : $4.2 \mathrm{~g}$, 酢酸 : $10 \mathrm{~mL}$, 蒸留水 : 10 $\mathrm{mL}$, エタノール : $70 \mathrm{~mL}$ )を用いて行った. 接合部の硬さ試 験はマイクロビッカース硬さ計により荷重 $0.49 \mathrm{~N}$ (保持時間 $15 \mathrm{~s}$ )で行った. 接合部等の結晶粒径は, 市販画像処理ソフ ト(Image Pro)を用いて測定した.

FSW 継手の機械的性質を評価するために，Fig. 1 に示す 寸法形状に加工した引張試験片（表裏を平滑になるまで研削） を用いて引張試験を行った。試験温度は室温で, 引張速度 (治具の移動速度)は, $8.33 \times 10^{-3} \mathrm{~mm} / \mathrm{s}$ である.

また，継手の機械的性質と結晶方位との関係を検討するた めに, 電子後方散乱回折 (EBSD) 法により, 継手の結晶方位 を調査した. EBSD 法にて分析を行うために TSL 社製の $\operatorname{SEM}(\mathrm{JSL}-6400)$ を用いた. EBSD 分析用試験片は, エメ リー紙 2000 番まで研磨した後, メタノール : $925 \mathrm{~mL}$, ブ タノール : $60 \mathrm{~mL}$, 過塩素酸 : $15 \mathrm{~mL}$ の混合液 $(253 \mathrm{~K})$ を用 いて電解研磨することにより，鏡面仕上げを行った。

\section{3. 実験結果および考察}

ショルダ径 $15 \mathrm{~mm}$-プローブ径 $5 \mathrm{~mm}$ (以後 $\phi 15-\mathrm{M} 5$ と表 記), ショルダ径 $20 \mathrm{~mm}$-プローブ径 $5 \mathrm{~mm}$ (以後 $\phi 20-\mathrm{M} 5$ と
表記) およびショルダ径 $20 \mathrm{~mm}$-プローブ径 $4 \mathrm{~mm}$ (以後 $\phi 20-$ M4 と表記)のツールを用いて, ツールの回転速度を一定と し, 接合速度を変化させて得られた RCPAZ31 継手の接合 部外観写真を Fig. 2 に示す。ツールの形状および接合速度 によらず，FSWの特徵であるショルダ径とほぼ一致した円 弧状の模様が接合開始点から終端部まで連続的に観察され, 接合面が滑らかな欠陥のない良好な継手が得られた. Fig. 3 に, $\phi 15-\mathrm{M} 5$, ショルダ径 $16 \mathrm{~mm}$-プローブ径 $4 \mathrm{~mm}$ (以後 \$16-M4 と表記) 抢よび $\phi 20-M 4$ のツールを用いて, ッール の回転速度を一定とし, 接合速度を变化させて得られた AZ31 継手の接合部外観写真を示す. RCPAZ31 継手と同様 に，ツールの形状および接合速度によらず，接合面が滑らか な欠陥のない良好な継手が得られた。

Fig. 4 に様々な形状のツールを用い, ツールの回転速度を 一定とし，接合速度を変化させて得られた RCPAZ31 継手 の引張試験結果を示す。ツール形状により継手効率(継手引 張強度 $/$ 母材強度 $(315 \mathrm{MPa}) \times 100)$ は大きく異なり，ショル ダ径が大きく, プローブ径が小さいほど継手効率は上昇する 傾向であった. $\phi 20-\mathrm{M} 4$ のツールで接合速度が $600 \mathrm{~mm} / \mathrm{min}$ の場合は, 引張試験片の接合部下部に未接合部が残存したた めに図中に示していない。この未接合部は, 接合速度の増加 とともに入熱量が減少し攪拌領域が接合部下部まで到達しな かったことと, 本研究では板厚 $2 \mathrm{~mm}$ に対してプローブ長 $1.8 \mathrm{~mm}$ と短めに設定したためであると考えられる. また, 接合速度がこれより遅い継手でも一部未接合部が観察された ことから，プローブ長は $1.8 \mathrm{~mm}$ 以上が適していると考えら れる. 最も高い継手効率が得られる条件は， $\phi 20-\mathrm{M} 4$ のツー ルで, $1250 \mathrm{rpm}-400 \mathrm{~mm} / \mathrm{min}$ で, 約 $90 \%$ (引張強度が約 $284 \mathrm{MPa})$ であった. 破断はいずれも SZ と TMAZ 境界近傍 (継手中央部から打抢々 2 $4 \mathrm{~mm}$ の位置)であった. 以上 のように, 本研究での条件範囲では, 微細結晶粒を持つ RCPAZ31 の FSW 継手の引張強度はツールの形状により大 きく異なることが明らかとなった。一方, Fig. 5 に様々な形 


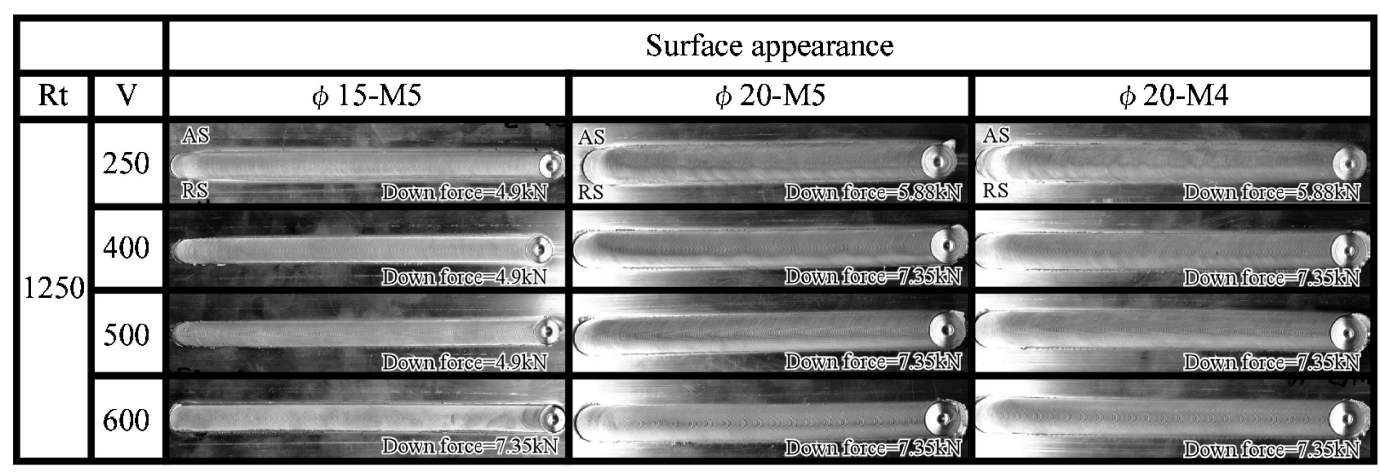

Fig. 2 Surface appearances of RCPAZ31 friction stir welds.

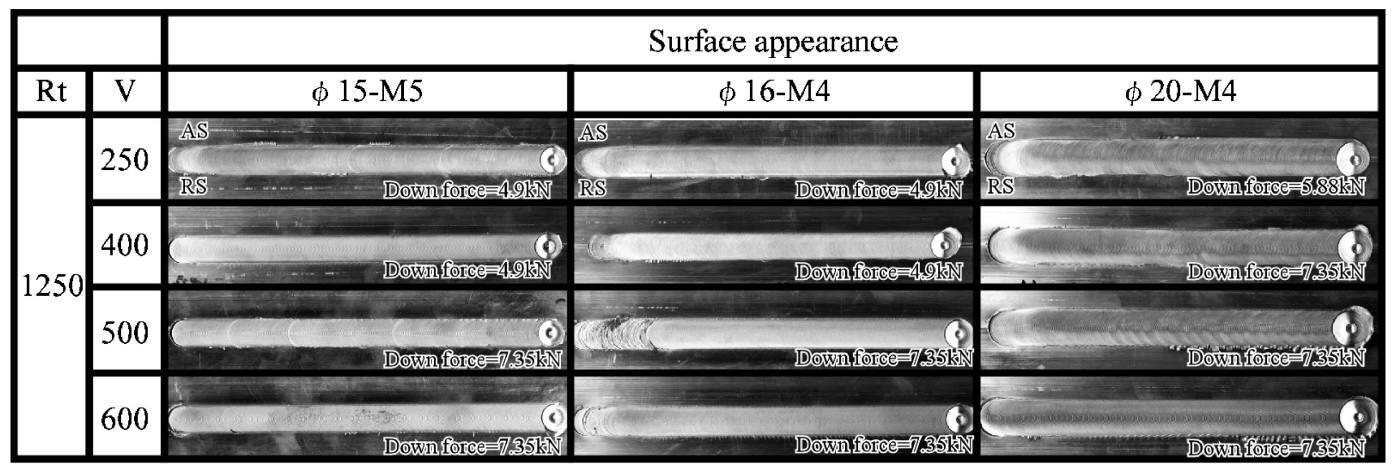

Fig. 3 Surface appearances of AZ31 friction stir welds.

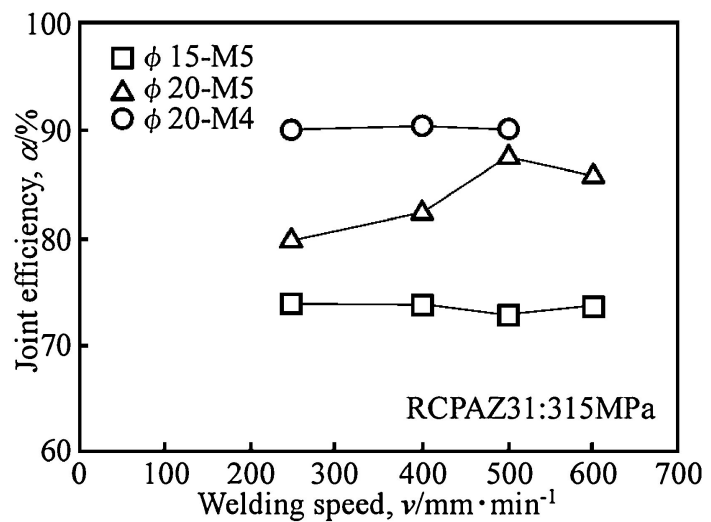

Fig. 4 Effects of welding speed and tool shape on joint efficiency of the RCPAZ31 joint.

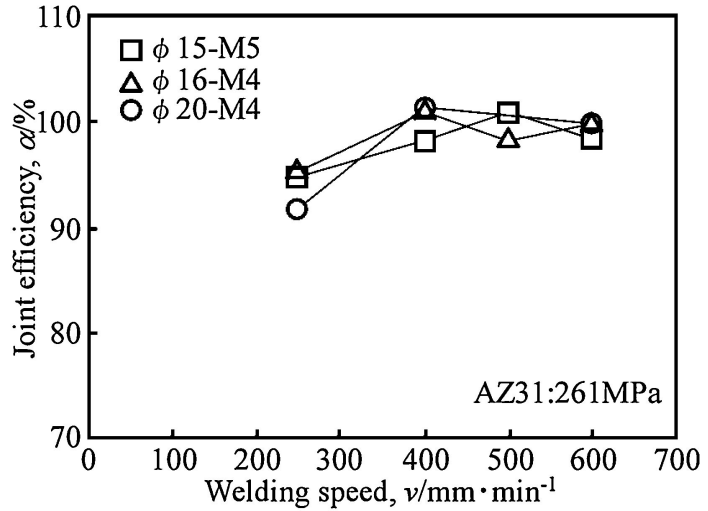

Fig. 5 Effects of welding speed and tool shape on joint efficiency of the AZ31 joint.
状のツールを用い, ッールの回転速度を一定とし, 接合速度 を変化させて得られた AZ31 継手の引張試験結果を示してい るが，ツール形状抢よび接合速度による継手効率の変化はほ とんど見られなかった， $\mathrm{mm} / \mathrm{min}$ の場合は, 引張試験片の接合部下部に未接合部が 残存したために図中に示していない。これは, 上述した RCPAZ31 の場合と同じ要因であると考えられるため, プ ローブ長は $1.8 \mathrm{~mm}$ 以上が適していると考えられる. 引張強 度はいずれの条件に扔いても，母材強度 $(261 \mathrm{MPa})$ と同程 度であり，継手効率は 90〜100\%であった。破断はいずれも $\mathrm{SZ}$ と TMAZ 境界近傍( 継手中央部から打よそ $2 \sim 4 \mathrm{~mm}$ の位置)であった. 以上のように, 本研究での条件範囲では, AZ31 押出材の FSW 継手の引張強度においては, ッール形 状の影響をほとんど受けないことが明らかとなった。

RCPAZ31に抢いて，高強度継手が得られた $\phi 20-\mathrm{M} 4$ と 低強度継手しか得られなかった $\phi 15-\mathrm{M} 5$ の接合速度が 250 $\mathrm{mm} / \mathrm{min}$ および $600 \mathrm{~mm} / \mathrm{min}$ の条件で得られた継手の接合 部断面の硬さ分布および各部で測定した平均結晶粒径を Fig. 6(a)〜 (d)に示す. いずれの条件においても, 各部の硬 さには若干のバラツキが見受けられるが, 攪拌部 (Stir Zone, 以下 SZ)では母材部と比較すると若干軟化してお り，その軟化した領域では結晶粒は粗大化していた。 また， ツール形状による硬さ分布の差異は認められなかったが, $\mathrm{SZ}$ の平均結晶粒径は, 接合速度の減少 (入熱量の増加) とと もに, 大きくなる傾向であった. ツール形状によって, 接合 部の平均結晶粒径はほとんど変化していないにも関わらず, 継手強度には大きな差があるのは, 結晶粒径以外の強度の支 

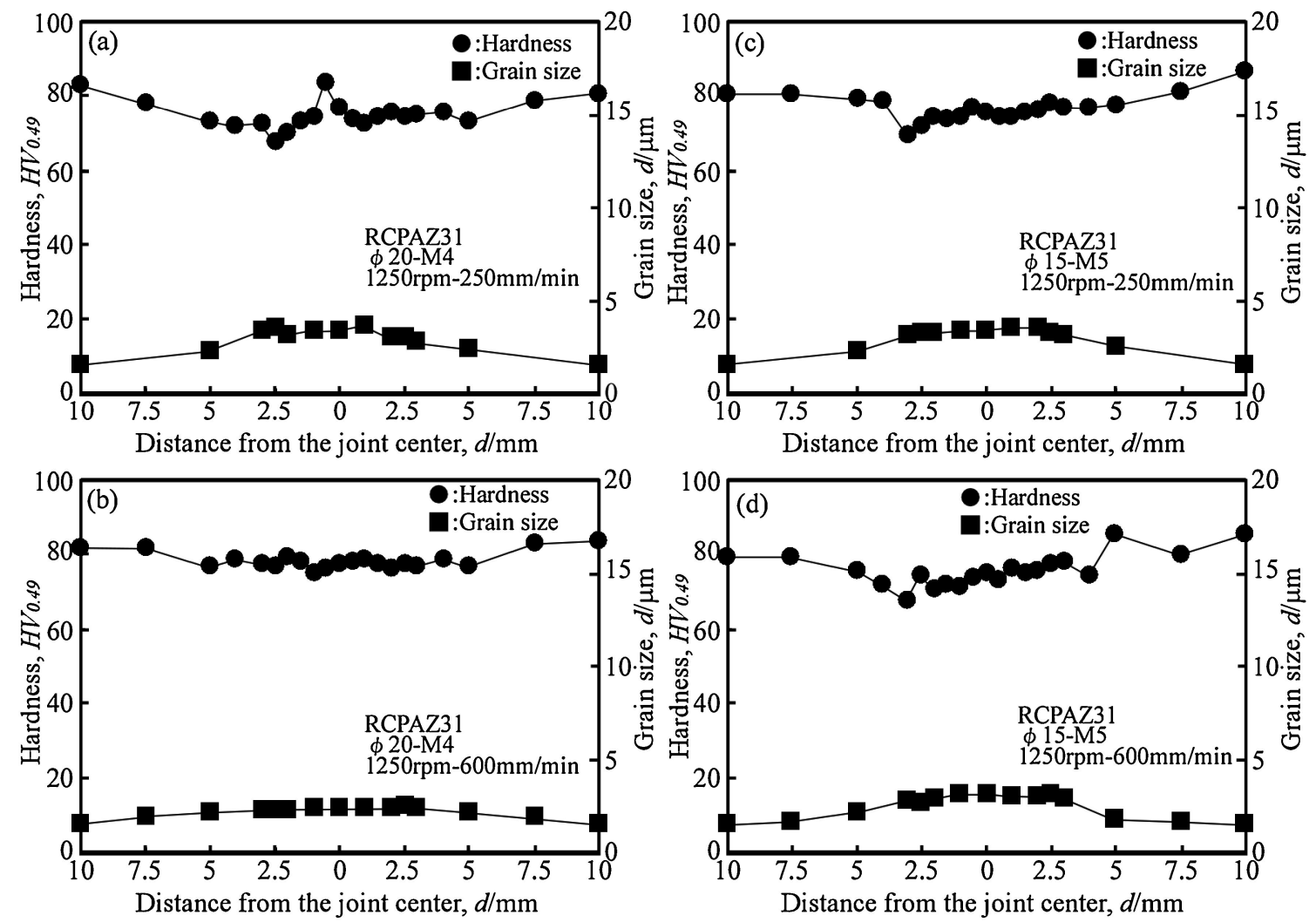

Fig. 6 Hardness and grain size distributions at RCPAZ31 joints: (a) $\phi 20-\mathrm{M} 4,1250 \mathrm{rpm}-250 \mathrm{~mm} / \mathrm{min}$, (b) $\phi 20-\mathrm{M} 4,1250 \mathrm{rpm}-600$ $\mathrm{mm} / \mathrm{min}$, (c) $\phi 15-\mathrm{M} 5,1250 \mathrm{rpm}-250 \mathrm{~mm} / \mathrm{min}$ and (d) $\phi 15-\mathrm{M} 5,1250 \mathrm{rpm}-600 \mathrm{~mm} / \mathrm{min}$.
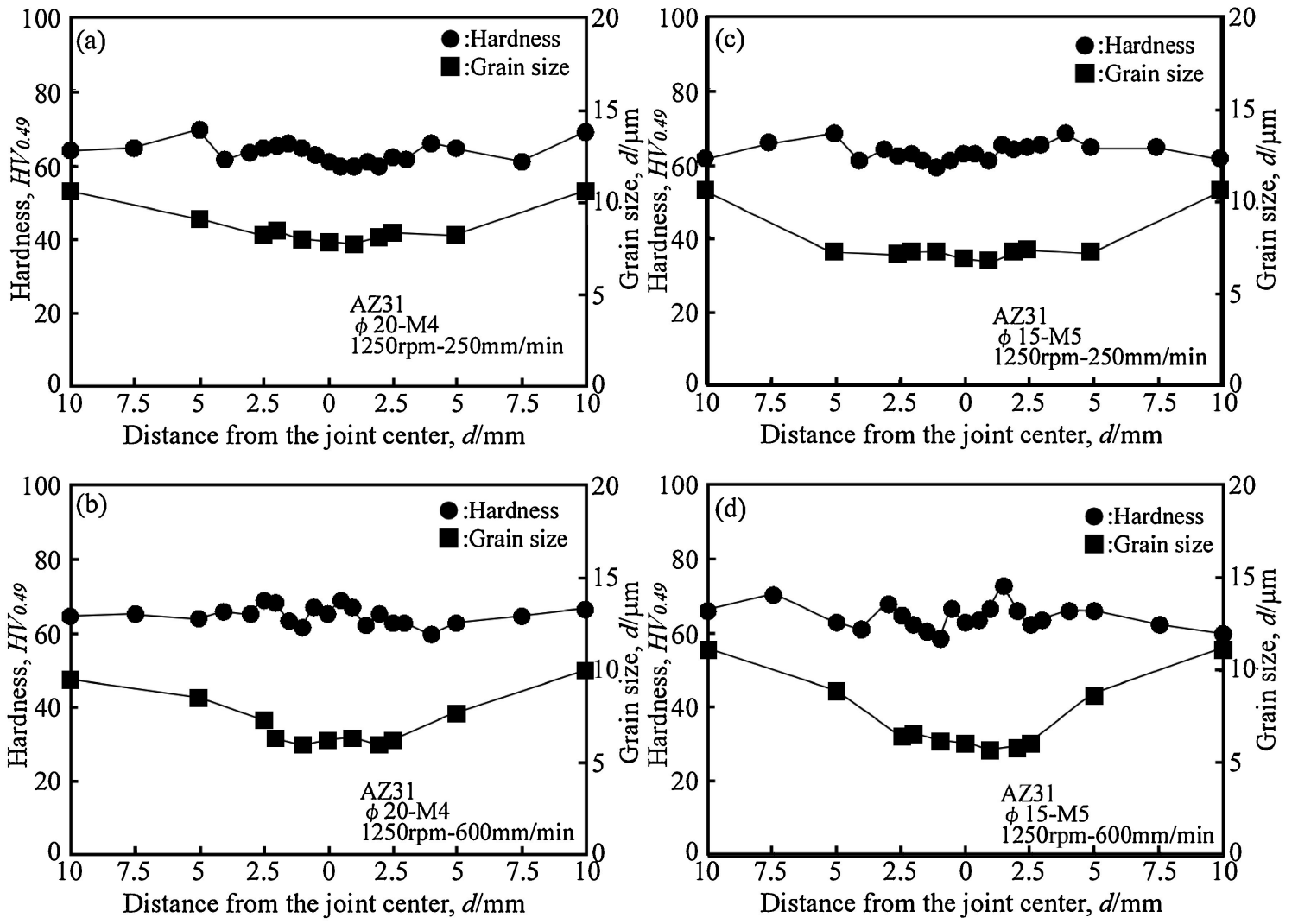

Fig. 7 Hardness and grain size distributions at AZ31 joints: (a) $\phi 20-\mathrm{M} 4,1250 \mathrm{rpm}-250 \mathrm{~mm} / \mathrm{min}$, (b) $\phi 20-\mathrm{M} 4,1250 \mathrm{rpm}-600$ $\mathrm{mm} / \mathrm{min}$, (c) $\phi 15-\mathrm{M} 5,1250 \mathrm{rpm}-250 \mathrm{~mm} / \mathrm{min}$ and (d) $\phi 15-\mathrm{M} 5,1250 \mathrm{rpm}-600 \mathrm{~mm} / \mathrm{min}$. 


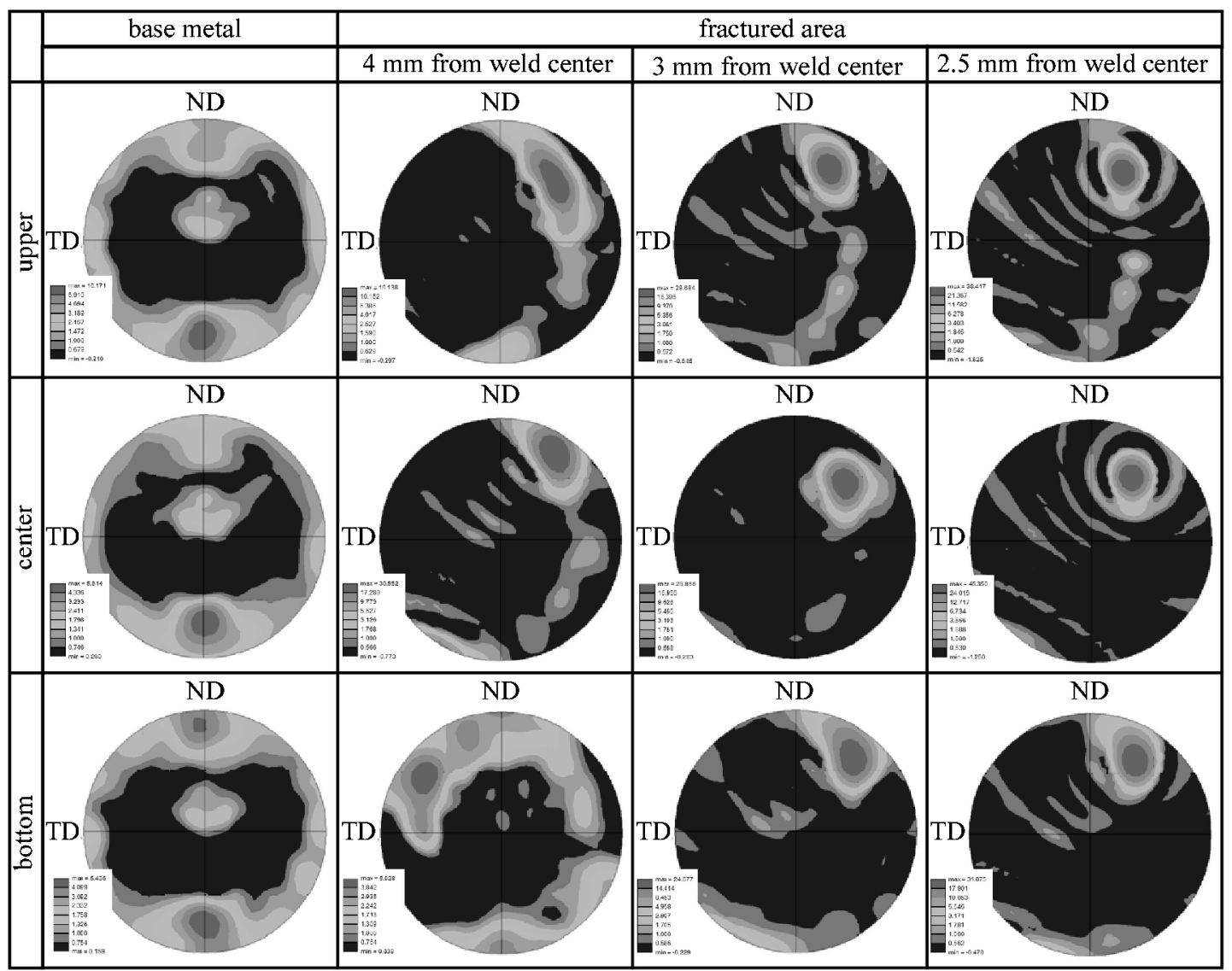

Fig. 8 (0002) pole figures obtained by OIM at the base metal and fracture region of RCPAZ31 joint under welding conditions of $\phi 15-\mathrm{M} 5$ and $1250 \mathrm{rpm}-250 \mathrm{~mm} / \mathrm{min}$.

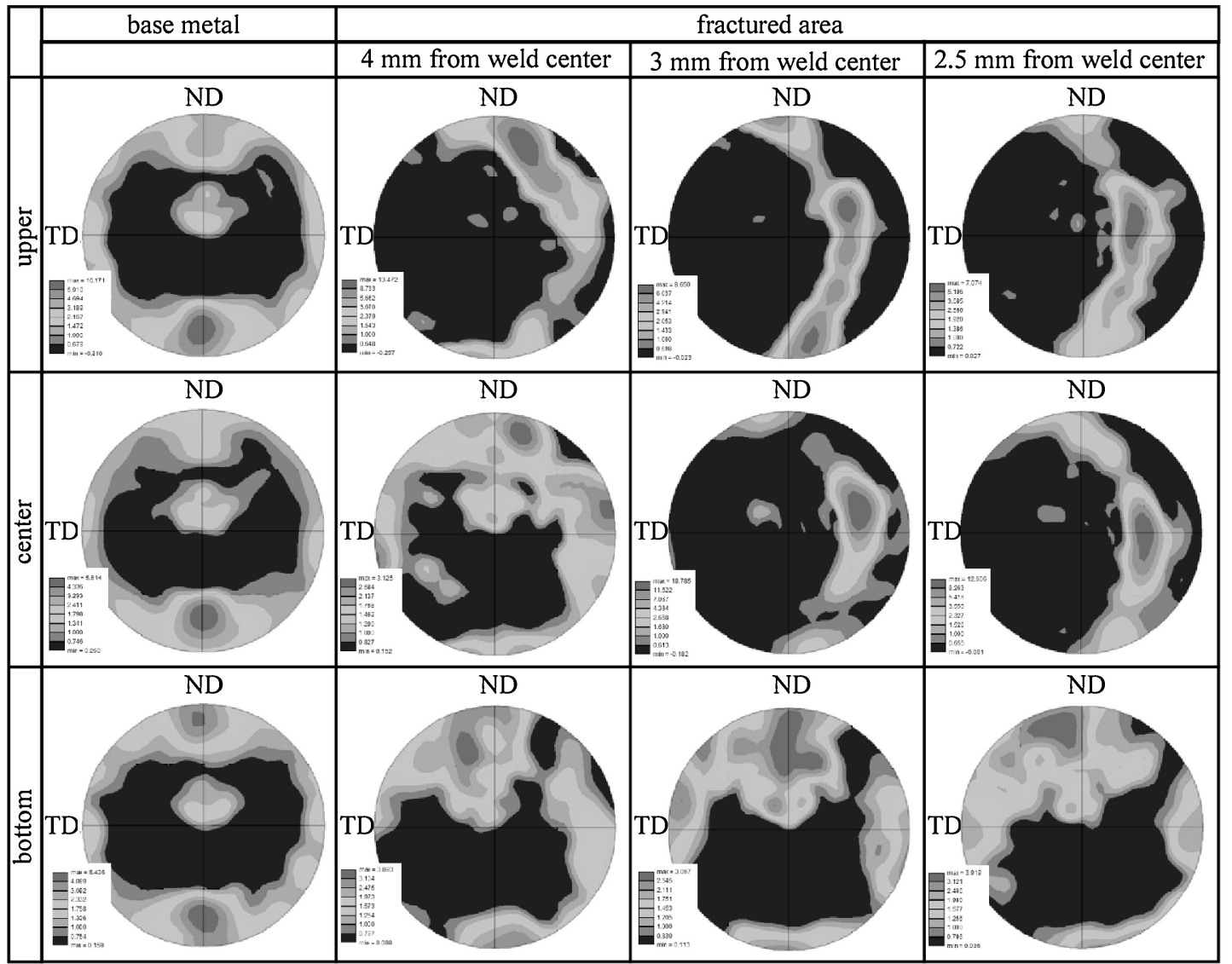

Fig. 9 (0002) pole figures obtained by OIM at the base metal and fracture region of RCPAZ31 joint under welding conditions of $\phi 20-\mathrm{M} 4$ and $1250 \mathrm{rpm}-250 \mathrm{~mm} / \mathrm{min}$. 
配因子である集合組織が異なると推察される，次に，AZ31 に拈いて， $\phi 20-\mathrm{M} 4$ および $\phi 15-\mathrm{M} 5$ のツールを用いて，接 合速度が $250 \mathrm{~mm} / \mathrm{min}$ および $600 \mathrm{~mm} / \mathrm{min}$ の条件で得られ た継手の接合部断面の硬さ分布および各部で測定した平均結 晶粒径を Fig. 7(a)〜 (d) に示す. いずれの条件においても， 各部の硬さには若干のバラツキが見受けられるが，SZでは 母材部と比較すると若干硬化しており，その硬化した領域で は結晶粒は微細化していた。 また，SZの組織は，接合速度 の減少 (入熱量の増加) とともに, 若干粗大化する傾向であっ た、ツール形状および接合条件によらず，継手効率の高い接 合継手が得られたのは接合部組織の平均結晶粒径が母材より 小さくなり, 結晶粒径以外の強度の支配因子である集合組織 の影響が小さくなったためと推察される.

以上のように，RCPAZ31 継手に拈いてはッール形状によ って, 継手強度に大きな差があるのは, 結晶粒径以外の強度 の支配因子である集合組織の影響力が異なると考えられるた め, 低強度継手しか得られなかった $\phi 15-\mathrm{M} 5$ と高強度継手 が得られた $\phi 20-\mathrm{M} 4$ の接合速度が $250 \mathrm{~mm} / \mathrm{min}$ の場合の継 手接合部(引張試験前)の結晶方位を EBSD で調査した. 得 られた $\{0002\}$ 面の極点図を Fig. 8 および Fig. 9 にそれぞれ 示す. $\phi 15-\mathrm{M} 5$ の場合，母材では上部，中心部および下部の いずれの箇所においても，\{0002 $\}$ 面は主に ND 方向 (押出材 板厚方向)を向いた(すなわち，\{0002 $\}$ 面が押出材表面と平 行する)集合組織を形成している。 つまり，\{0002\}面が引張 方向と平行する。破断が生じた領域(接合部中央から $2 \sim 4$ $\mathrm{mm}$ 離れた箇所)では，上部，中部拈よび下部では，引張方 向と打抢よそ $45^{\circ}$ をなす集合組織を形成していた。一般的 に, 引張荷重の分解せん断応力は, 引張方向と $45^{\circ}$ をなを きに最大となる.すなわち, 破断した領域では, すべり面で ある $\{0002\}$ 面が引張方向と $45^{\circ}$ に近い角をなしており，その 他の領域に比べて容易に降伏したと考えられる．そのため に，局部的な伸びしか得られなかったために，継手の引張強 度が減少したと考えられる．ちなみに， $\phi 15-\mathrm{M} 5$ で接合速度 が $250 \mathrm{~mm} / \mathrm{min}$ の接合条件で得られた AZ31 継手接合部の 集合組織分布も，同様の傾向であった。一方， $\phi 20-\mathrm{M} 4$ の場 合は，破断が生じた領域（接合部中央から $2 \sim 4 \mathrm{~mm}$ 離れた 箇所)では，下部では $\{0002\}$ 面は主にND方向を向いた集合 組織を形成しており，上部抢よび中部では，お拈よそ TD 方向(押出材の幅方向)を向いた集合組織を形成している.つ まり，いずれの箇所においても集合組織の $\{0002\}$ 面は母材 と同様に引張方向に抢抢よそ平行か垂直であり, 引張強度を 低下させる要因となる引張方向と $45^{\circ}$ をなす集合組織が形成 されなかったために，高強度の継手が得られたと考えられ る. また, 以上のような継手強度への結晶方位の影響は, Park ら ${ }^{4)}$ の AZ61の FSW 継手で報告されている結果と同様 である。このことから，RCPAZ31の FSWにおいては， ツール形状による組織制御は可能であり, 本研究材において はショルダ径とプローブ径の比が大きいほど良いと考えられ
る. 以上のように，微細結晶粒を持つ $\mathrm{Mg}$ 合金の FSW にお いては, 接合条件だけでなくッール形状も十分に検討する必 要があると考えられる.

\section{4. 結言}

$\mathrm{RCP}$ 工法によって得られた微細結晶粒を持つ RCPAZ31 および AZ31 押出材に FSW を適用し, 得られた継手の組織 と機械的性質に及ぼす接合条件およびッール形状の影響を検 討した結果，以下の結論を得た.

(1) RCPAZ31 継手の引張強度は，ッール形状により大き く変化するが, AZ31 継手の引張強度は, ツール形状によっ てほとんど変化しないことが明らかとなった。

(2) RCPAZ31 での最適接合条件は，ツール形状がショル ダ径 $20 \mathrm{~mm}$ でプローブ径が $4 \mathrm{~mm}$ であり，ツールの回転速 度が $1250 \mathrm{rpm}$ で接合速度が 250〜 $600 \mathrm{~mm} / \mathrm{min}$ であった。

（3） RCPAZ31 継手の攪汼部は平均結晶粒径が母材と比較 して若干粗大化しており軟化していた. 平均結晶粒径は, 接 合速度の増加により，わずかであるが小さくなる傾向であっ た. 一方, AZ31 継手の覺找部は平均結晶粒径が母材と比較 して微細化しており硬化していた. 平均結晶粒径は, 接合速 度の増加により, 若干小さくなる傾向であった.

(4) 最適接合条件で得られた接合継手の継手効率は, RCPAZ31 およびAZ31 ともに $90 \%$ 以上であった。 RCPAZ31 継手の引張強度は主に攪拌部に形成される集合組 織の結晶方位に依存していることが明らかとなった.

本研究に対して有益なご討議を頂きをした大阪大学接合科 学研究所津村卓也助教に深謝いたします.

文 献

1) K. Katoh, H. Tokisue and T. Kitahara: Journal of Light Metal Welding \& Construction 42(2004) 130-139.

2) W. B. Lee, Y. M. Yeon and S. B. Jung: Mater. Sci. Technol. 19 (2003) 785-790.

3) S. H. C. Park, Y. S. Sato and H. Kokawa: Metall. Mater. Trans. A $34(2003)$ 987-994.

4) S. H. C. Park, Y. S. Sato and H. Kokawa: Scr. Mater. 49 (2003) 161-166.

5) K. Katoh, H. Tokisue and T. Kitahara: J. JILM 55(2005) 259264

6) K. Nakata, S. Inoki, Y. Nagano, T. Hashimoto, S. Johgan and M. Ushio: J. JILM 51(2001) 528-533.

7) M. Fujie, K. Nakata, M. Ushio, H. Yamaguchi and T. Tukeda: Preprints of the National Meeting of JWS 73(2003) 54-55.

8) K. Katoh and H. Tokisue: Preprints of the National Meeting of JWS 75(2004) 14-15.

9) N. Yamamoto, J. Liao and K. Nakata: J. Japan Inst. Metals 72 (2008) 538-543.

10) J. Liao, N. Yamamoto and K. Nakata: Metall. Mater. Trans. A 40 (2009) 2212-2219.

11) K. Kondoh: Magnesium Technology 2005, (2005) pp. 77-80.

12) J. Liao, M. Hotta, K. Kaneko and K. Kondoh: Scr. Mater. 61 (2009) 208-211. 